\title{
Analysis of Public Participation in Sustainable Waste Management Practice in Abuja, Nigeria
}

\author{
Ebikapade Amasuomo (Corresponding author) \\ SEBE, Glasgow Caledonian University, Cowcaddens Road, G4 0BA Glasgow, UK \\ Tel: 44-796-423-8677_E-mail: ebiyoko@yahoo.co.uk \\ Omagbemi Jessica Aghogho Tuoyo \\ SEBE, Glasgow Caledonian University, Cowcaddens Road, G4 0BA Glasgow, UK \\ E-mail: jessyparkar@yahoo.com
}

Syed Ali Hasnain

Centre of Excellence in Sustainable Building Design, School of Energy, Geosciences

Infrastructure \& Society, Heriot-Watt University, EH14 4AS, Edinburgh, UK.

Received: March 19, 2015 Accepted: April 7, 2015

doi:10.5296/emsd.v4i1.7269 URL: http://dx.doi.org/10.5296/emsd.v4i1.7269

\begin{abstract}
It is widely accepted that solid waste management is a global problem. This problem is even more pronounced in developing countries such as Nigeria where solid waste management is a major concern. In recent times, however, there has been a concerted effort towards engaging members of the public in solving the waste management crisis. This effort is centred on public participation in sustainable waste management practice across the country. Nevertheless, in Abuja there seems to be low public participation in sustainable wastes and environmental management practice. This paper therefore seeks to investigate the rate of participation in sustainable waste and environmental management activities in Abuja. In order to achieve the aim of the study, the paper relied on a sample of 57 participants to obtain some primary data. The paper employed a mixed method approach with the aid of a questionnaire. The questions were designed to gather data on demographics of the participants, their awareness and attitude to sustainable waste management, the barriers preventing public participation in a sustainable solid waste management and measures that can encourage
\end{abstract}


public participation in sustainable waste management in Abuja. The study revealed that increase funding, provision of recycling collection points, enforcement of laws and policies, the development of effective policies and regulatory framework amongst others are some of the measures that can encourage public participation in sustainable waste management programs in Abuja.

Keywords: Public Participation, Waste Management, Nigeria

\section{Introduction}

It is widely accepted that the management of solid waste is a global problem. This problem is even more pronounced in developing countries such as Nigeria where solid waste management is a major concern(Butu and Mshelia, 2014). Adeyemi et al, (2001) observed that solid waste constitute a major problem in most developing countries. Adeyemi added that waste management is one of the most intractable problems facing city administrators and environmental agencies. Ogwueleka, (2009) reported that solid waste management is by far one of the greatest challenges facing environmental bodies in the country. As a result of the management challenges, Adefemi and Awokunmi, (2009) reported a breakdown of law and order in relation to waste management. They observed that urban centres are experiencing an increased rate of environmental deterioration as a result of indiscriminate dumping of solid waste.

Omuta, (1987) noted that one notable flaws in waste management administration in developing countries is the unavailability of a proper waste management policy. His view is that for waste management to work, various aspects of Government services such as engineering, urban planning, Geography, economics, public health and law among others must be brought together under a proper policy to deliver an effective waste management system. Ogwueleka (2009) argues that some of the approaches used in tackling the waste problems in Nigeria have recorded very little success. He observed that, the approaches do not distinguish the different needs and diversities of the different cities in the country. He added that these approaches are capital intensive and bureaucratic.

The recent efforts of some waste management agencies in Nigeria aimed at involving members of the public in waste management operations have not yielded positive response from the public (Ogunba, 2004). However, it is important to note that, factors which influences public response and participation in waste and environmental sanitation issues includes; the presence or absence of appropriate facilities, policies for waste disposal and low awareness of the problems associated with poor waste management. Consequently, bridging the information gap and understanding the challenges of the Nigerian public involvement in sustainable waste management practice will be helpful in developing appropriate measures including behaviour-modifying measures (Imam et al., 2008; Adewole 2009). This approach may strengthen and complement the current sustainable waste management strategy in the country.

\subsection{Waste Management in Abuja}

Ogwueleka, (2009) pointed out that due to the developing nature of Abuja, there are several 
ongoing constructions projects which have resulted in many abandoned excavation sites across the city. Consequently, these excavation sites are converted to temporary landfill or dumpsites by residents and the municipal authority (Imam et al., 2008). Babayemi and Dauda (2009) reported that huge piles of wastes along these illegal dump sites are some of the characteristics of waste management in Abuja. Similarly, Saeed et al. (2009) reported that landfilling and disposal of wastes on illegal dumps and temporal landfill sites are common practice in the city.

Although historically landfills are thought to be an important ultimate disposal option for solid wastes (Al-Jarrah and Abu-Qdais, 2006). Saeed et al. (2009) however, argue that landfills have various environmental impacts. The environmental impacts of landfills are very costly especially in terms of health implications for those living around the landfill sites (Ogwueleka, 2009). The impacts of landfills may vary from one region to another depending on the types and composition of the wastes on the landfill and the terrains of an area (Suberu et al., 2012).

Nevertheless, the introduction of a good waste management practices in Abuja will improve the quality of life of the city's residents. The positive effects of good waste practice in Abuja can be discussed on the basis of environmental effects and economic effects (Onwughara, et al., 2010).Good waste management practice in Abuja will results to a reduction in surface water contamination. Good quality water is one of the most essential requirements to sustain life. Therefore, a good waste management practices in the city will reduce the amount of wastes that end up in water bodies (Onwughara, et al., 2010). Remigios (2010) argues that every living thing requires good and safe water for drinking and other uses. Safe and good water is only attainable when the level of water pollution is significantly reduced or eliminated altogether (Umesi and Onyia, 2008).

Another positive environmental benefit that will arise from sustainable waste management practices in Abuja is the reduction in soil and environmental pollution. According to Arene and Mbata (2008) and Nzeadibe and Ajaero (2011), hazardous chemicals that are derived from wastes changes the chemical composition of soil, which can result in the destruction of crops and plants. Given that most of the people living in Abuja are farmers, increased poor wastes management is likely to results into poor soil quality and low agricultural yield. A move towards sustainable waste management practice however will minimize soil pollution and improve agricultural yield (Abba, et al., 2013). Furthermore, a better waste management practices in Abuja will results to a reduction in air pollution from the burning of refuse and a better environment capable of supporting biodiversity and a balanced ecosystem (Manhart et al., 2011).

\section{Research Design and Methodology}

The research utilized a mixed method approach for the study. A mixed method approach entails the use of both qualitative and quantitative research approaches. Qualitative research approaches employs the use of non-numerical data while quantitative research involves the use of numerical data (Bryman, 2012). In order to achieve the objectives of the study, both secondary and primary data were collected. Secondary data involved the collection of data 


\section{Macrothink}

from existing literatures such as books, journals, articles, and websites of Abuja and other environmental organisations. Primary data on the other hand were obtained directly from the randomly selected participants.

\subsection{Research Instruments}

The study employed questionnaires as the main instruments for data collection. The questions were arranged into four sections. Section one was aimed at collecting data on participants demographics; section two collected information on the awareness and attitude to sustainable waste management amongst the participants; section three of the questionnaire contains questions on the barriers preventing public participation in a sustainable solid waste management. Section four was designed to gather data on measures that can encourage public participation in sustainable waste management in Abuja.

\subsection{Sampling Size and Technique}

Through a simple random sampling method, the study selected 57 participants to gather data. Simple random sampling was preferred to other sampling methods since it gave every resident an opportunity to be selected for the study. The participants were randomly selected from Abuja and especially within the Abuja Municipal Council area. The study participants were mostly from the following areas of Abuja; Abuja Municipal Area Council, Abaji Area Council, Gwagwalada Area Council, Kuje Area Council, Bwari Area Council, and Kwali Area Council areas. Table 1 below represents a breakdown of total participants per council area.

Table 1. Random Sampling of the Participants

\begin{tabular}{|l|c|}
\hline \multicolumn{1}{|c|}{ Council Area } & Number \\
\hline Abuja Municipal Area Council & 12 \\
\hline Abaji Area Council & 10 \\
\hline Gwagwalada Area Council & 8 \\
\hline Kuje Area Council & 11 \\
\hline Bwari Area Council & 9 \\
\hline Kwali Area Council & 7 \\
\hline Total & 57 \\
\hline
\end{tabular}

\section{Results and Discussions}

The demographics of the participants are presented in section one of the questionnaire. Figure 1, present information on the gender, age, and how long the participants had been living in Abuja. The results of the study are illustrated below: 


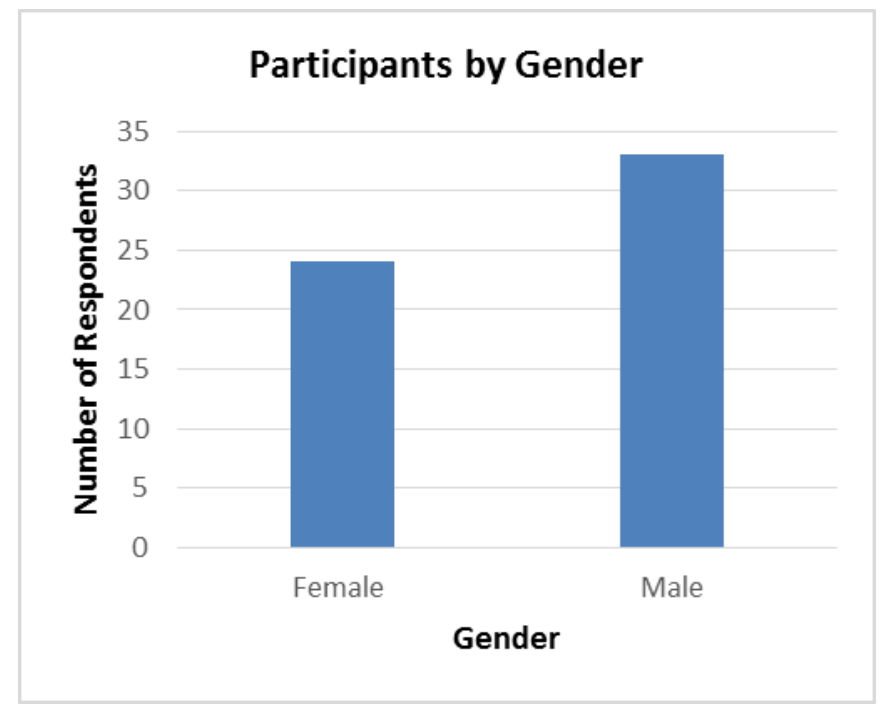

Figure 1. Gender of the participants

From figure 1 it can be inferred that out of the 57 participants, $57.9 \%$ were male whereas $42.1 \%$ were female. The above results imply that there were more males than females amongst the 57 participants selected for the study.

The study also sought to establish the composition of the population in terms of age. Age composition is important in order to ensure that participants were old enough to understand wastes and environmental issues. A graphical representation of the ages of participants is presented in figure 2 :

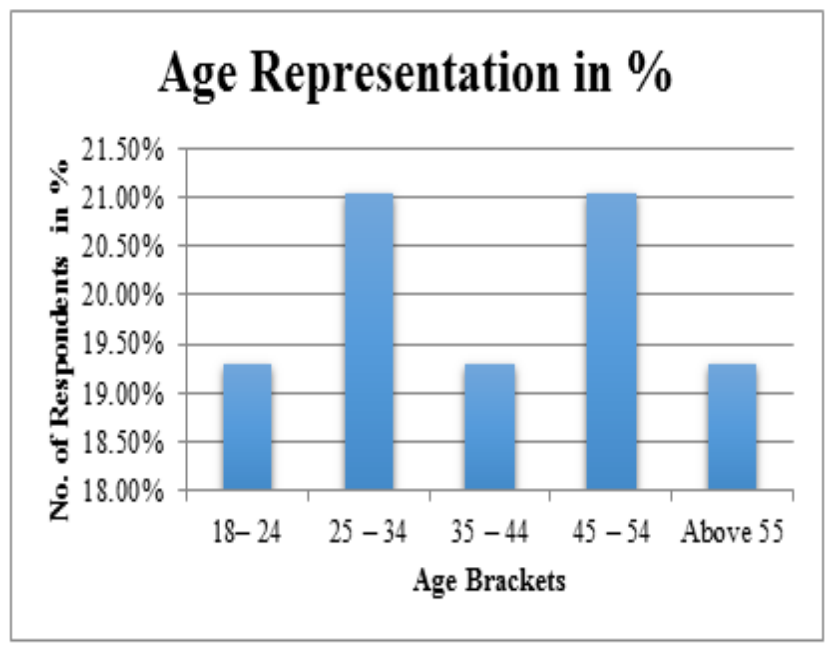

Figure 2. Age of the participant

According to the above figure, majority of the participants $(21.1 \%)$ are between two age groups 25 to 34 and 45 to 54 years old. The other age groups are more or less the same. Figure 2 also revealed that majority of the participants are more than 25 years old and therefore suitable to take part in the study.

Other than establishing the age group of the participant; the study sought to find out the 


\section{Macrothink}

number of years that the participants had spent in Abuja. It was imperative to determine the duration of time spent in Abuja by each participant in order to determine their suitability for the study. The following are the results of the responses obtained from the participants as displayed in figure 3 , the results reflect a wide range of age groups.

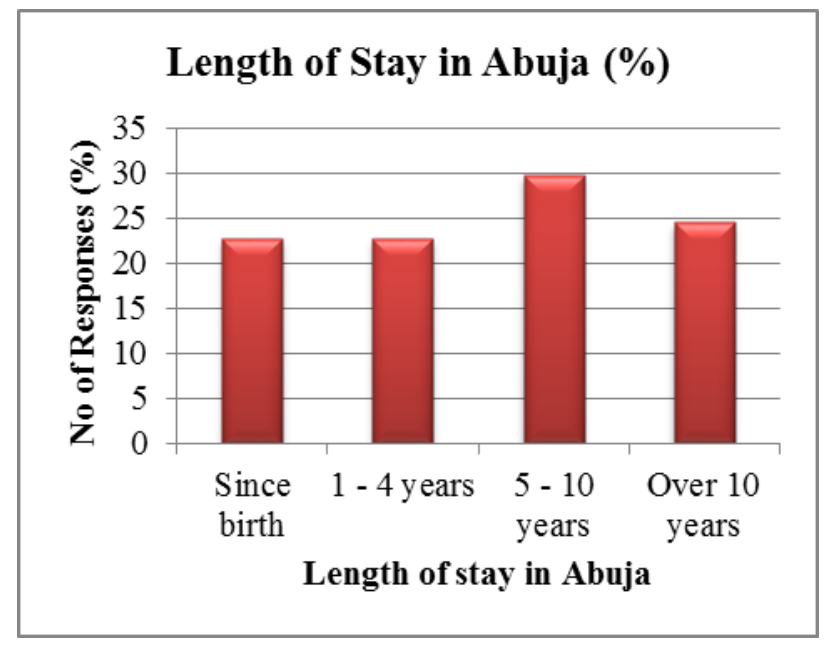

Figure 3. Duration of stay in Abuja

Based on figure 3, it is evident that majority of the participants, $29.8 \%$ have spent between 5 and 10 years in the city. While, $24.6 \%$ have spent over 10 years in Abuja; $22.8 \%$ of the remaining participants had spent between 1 to 4 years and all their life in the city.

From the above results, it is evident that most of the participants had lived long enough in Abuja therefore they were suitable to answer questions on waste management in the city. This information is necessary in order to ensure that the participants understand waste management operations in the city.

\section{Awareness and attitude of the people towards solid waste management}

Some of the questionnaire items were aimed at establishing the awareness and attitude of the participants and the entire population to sustainable solid waste management. Question four of the questionnaire asked, "Do you recycle any of your waste? 'From the response, only $43.86 \%$ of the respondents confirmed that they engage in recycling of wastes whereas the remaining $56.14 \%$ of the respondents claimed that they do not engage in recycling. Recycling is a form of sustainable waste management and when a region has a low number of people engaging in recycling, it may be an early indication of poor waste management practice in the city. In this respect, it seems that waste management in Abuja is far from sustainable. Figure 4 is a graphical illustration of the response obtained. 


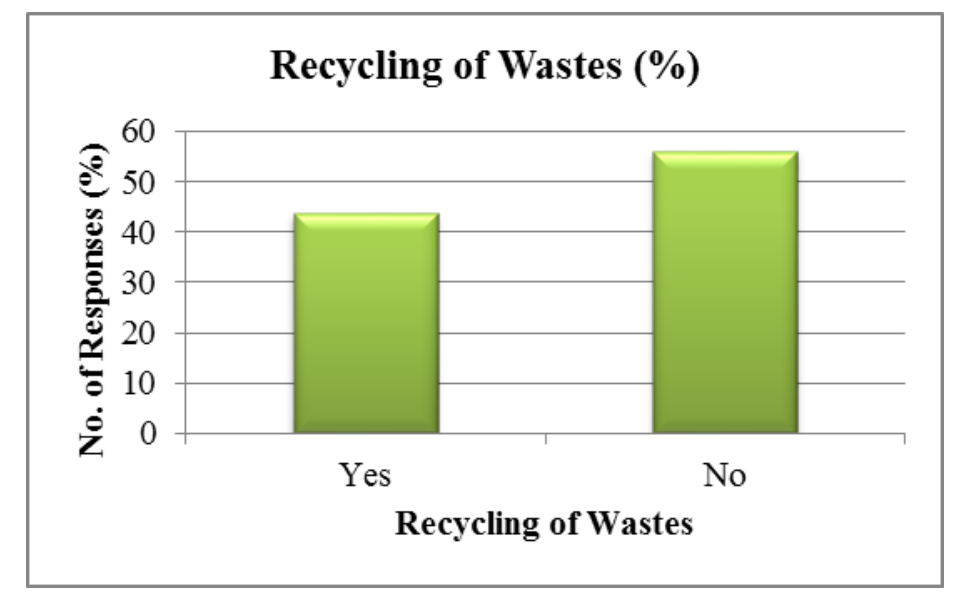

Figure 4. Recycling of wastes among participants

Separation of waste before disposal

An important aspect of sustainable waste management is separation of wastes at source. According to the responses, $35.09 \%$ of the respondents engage in separation of wastes whereas $64.91 \%$ of the respondents do not engage in separation of wastes. In this respect, it is evident that most people in Abuja do not separate their wastes. The responses of the participants are illustrated in figure 5:

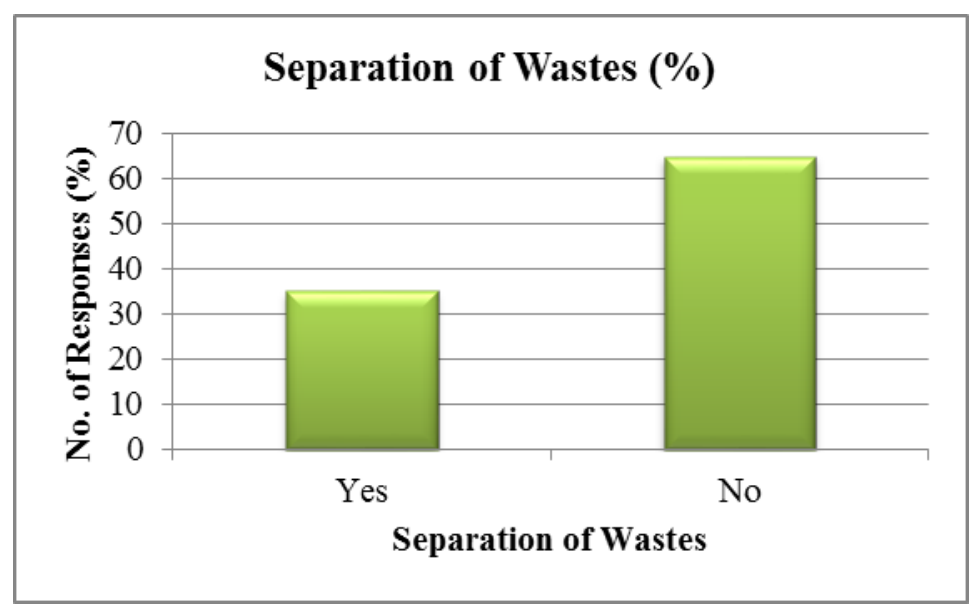

Figure 5. Participants that separate wastes

\section{Consideration towards value of disposed items}

Valuing waste is a concept that explains the knowledge and awareness of the respondents towards the wastes that they produce. The responses obtained from the participants are illustrated below: 


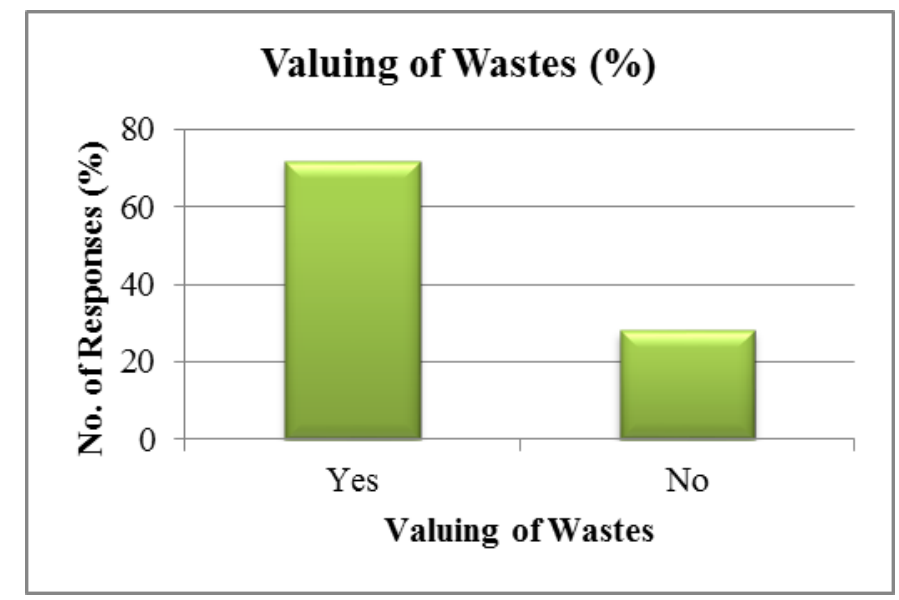

Figure 6. Value of the wastes

From the responses obtained, $71.93 \%$ of the respondents claim that they place a value on their wastes whereas the $28.07 \%$ said that they do not value wastes. From the statistics, it is evident that a high percentage of the residents in Abuja believe that wastes have value. However, only a few people actually engage in waste separation and recycling. This may be attributed to the lack of incentives for residents who engage in recycling activities unlike in some cities such as Curitiba, Brazil where residents exchange recyclable waste for food, the so call "Food for trash" program. This may likely be the reason for the low participation in waste separation and recycling as revealed in this study.

\section{Composition of the waste}

In regards to the composition of the wastes, figure 7 shows that majority of the respondents admitted that the wastes are mainly composed of food and other domestic materials. The responses were grouped into mainly food, bottles, plastics, papers and others.

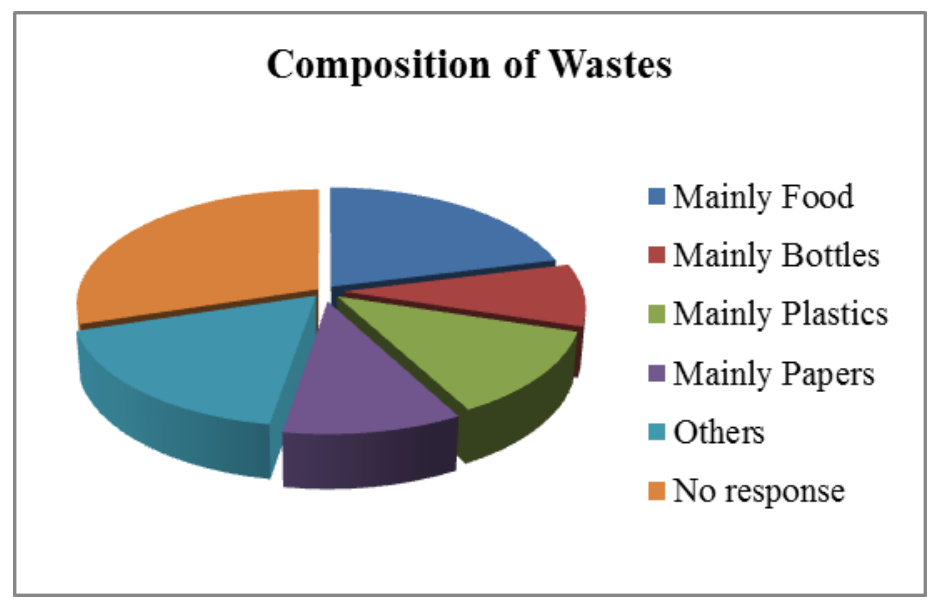

Figure 7. Pie representation of different waste composition

Apparently, based on the analysis of the primary data collected, it is obvious that public involvement in environmental sanitation issues in Abuja is very low. Members of the public assume that environmental sanitation is the sole responsibility of the government. This is evident from the findings of the survey and from the information volunteered by the 
participants. A higher public involvement in environmental sanitation issues is likely to ensure a clean and healthy environment. Therefore, adequate measures must be taken by the environmental protection board to ensure a high level of public participation. These measures may include the provision of incentives such as free waste disposal bins and some form of reward to those who engaged in good waste management practice.

When the participants were asked, "Are there waste bins and other facilities to encourage waste collection, transportation, and disposal in Abuja" From figure 8, it can be seen that $73.68 \%$ responded "yes" to the question while $26.32 \%$ responded "no".



Figure 8 . Availability of the waste bins

In this case, the majority of the participants agreed to the fact that the government have put in place facilities such as waste bins with a view of encouraging waste collection, transportation and disposal. However, some of the participants believe that the available facilities cannot adequately serve the population of Abuja. Hence, government needs to increase the number of communal and individual household bins as well as waste collection trucks to meet the need of the city. Indeed, government has an important role to play in initiating a move towards sustainable waste management in Abuja.

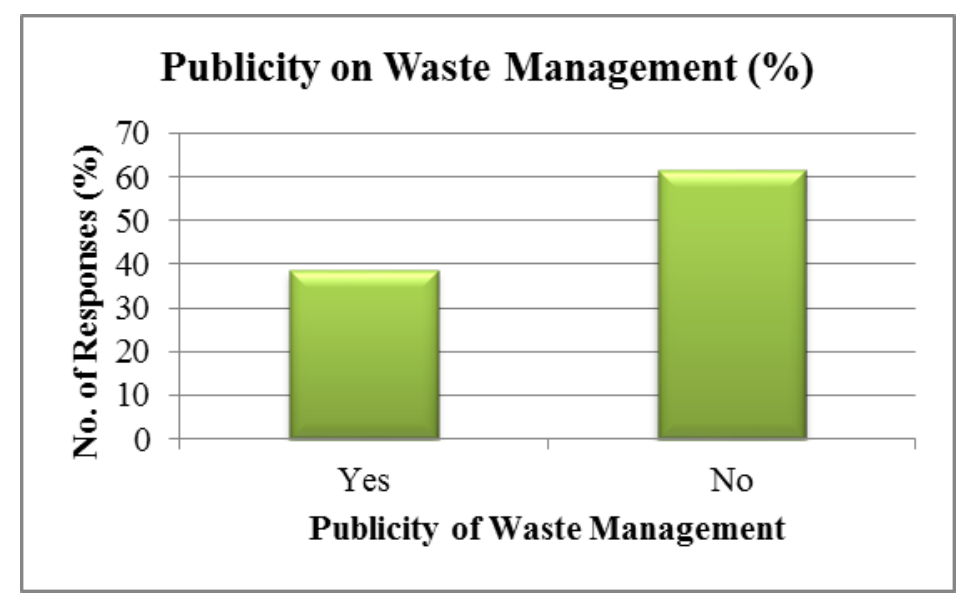

Figure 9. Publicity for waste management 
Awareness and education are important tool capable of increasing public participation in sustainable waste management programs. Figure 9 shows that, majority (63\%) of the participants confirmed that the publicity of waste management activities is quite low. It is evident that the lack of information and publicity has largely contributed to the low public participation in sustainable waste management practice in Abuja. Participants argued that the government of Abuja should be actively involved in making sure that every member of the public is involved in waste management through the creation of awareness over various media.

Secondary data revealed that the obstacles to public participation in waste management includes; lack of funding, inadequate government policies, environmental programs, and behaviour of the public (Philippe and Culot, 2009). Inadequate funding limits the amount of resources both capital and human that are required in waste management. Poor environmental programs by waste management agencies make it difficult for members of the public to effectively engage in sustainable waste management activities. To this end, the government should invest in programs capable of encouraging public participation in sustainable waste management programs.

Besides funding and low awareness other steps that could boost public participation includes the development of effective policies towards waste management. Effective policies towards sustainable waste management programs are very important in enhancing the public participation. Through effective policies, Suberu et al. (2012) argue that waste management agencies will encourage a better level of public participation in solid waste management. Public participation in waste management requires effective guidelines in terms of policies and regulations. Solomon (2009) and Ukem (2008) argue that public participation can be enhanced through effective policies and regulations such as the passage of law on reuse and recycling of waste in Abuja; and the enactments of laws to enforce the use of communal bins. The study revealed that use of effective policies and regulatory frameworks can be useful in enhancing public participation in sustainable solid waste management.

\section{Barriers preventing public participation in sustainable solid waste management}

Majority of the respondents stated that the main barriers that prevent members of the public from taking active role in waste management includes; the lack of information on how and where the wastes are to be disposed, unwillingness of the public due to wastes and environmental levies, lack of adequate support from the government and other stakeholders, and poor government policies amongst others.

\section{How to encourage members of the public to play active role in managing waste properly?}

From the response obtained, it is evident that the participant strongly believed that some of the measures that can encourage public participation in sustainable waste management in Abuja includes; increase resources both capital and human as well as increased publicity and awareness. 
Lastly participants were asked to volunteer any other comments; the question was asked as follows, "Are there any other comment or suggestion that you may have which could help improve public participation in waste management in Abuja".Although most of the participants did not have additional comments, the few who made general comments complained that

- Waste management in Abuja is really poor and that there is an urgent need to address the situation especially in terms of indiscriminate waste disposal in the city.

What's more, the participants complained that with

- The poor disposal of waste there is likely to be emergence of serious health issues and other complications associated with poor solid waste management.

While thanking the researcher for investigating and identifying ways of promoting public participation in waste management; the participants opines that there is a need for more studies on the same subject not only in Abuja but also across Nigeria.

Factor Analysis

This section presents a summary of the findings upon the utilization of factor analysis on the questionnaire data. The analysis is limited to establishing the correlation among variables.

The preliminary factor analysis utilised some of the following variables; information such as gender, age, length of stay of participants and the awareness and attitude to sustainable waste management amongst the participants.

Preliminary analysis revealed that no visible correlation exist between gender and awareness to solid waste management issues. The data showed that other factors such as publicity were more likely to play an important role to the level of awareness of an individual to waste management issues than the gender of an individual. Hence, the men that participated in the study were not better informed or more aware of solid waste management issues than the female participants. Therefore it can be inferred that the gender of an individual does not guarantee an increased level of awareness to waste management issues in a city. Similarly, the age of the participants showed no significant relationship with awareness to solid waste management issues. Hence younger participants were not likely to be more informed or aware of waste management issues than the older participants and vice versa. In addition, younger participants in the study were not found to have a better attitude to waste management than the older participants. Consequently, the age of an individual has no significant relationship with his/her attitude towards solid waste management issues. This is consistent with the findings of D'Elia, (2008).

Furthermore, the gender of the participants was found to have no significant correlation with the variables on waste recycling and waste separation. People were more disposed to recycling and waste separation as a result of their awareness on environmental issues and not because they are male or female. Hence, men are not likely to separate or recycle their wastes more than women and vice versa. This is consistent with a similar study (D'Elia, 2008) which reported that gender has no significant relationship with recycling behaviour. 


\section{Macrothink}

The attitude and awareness of the participants is likely to be positively influenced with increased publicity on waste management issues. It was found that the more the public are informed on waste management issues, the better their perception and attitude towards environmental issues. It was found that majority of participants who responded that there is enough publicity on waste management in Abuja also confirmed that they recycle and separated their wastes. Therefore, publicity increase awareness, and with increased awareness, residents were more disposed to participating in recycling activities. This is consistent with a study (Rahardyan, et al., 2004) which reported that participation in recycling of household waste relies on the level of awareness and understanding of recycling. Improved education and increasing the accessibility of recycling facilities are the best means of promoting positive attitudes to recycling attitude, partly because they help to remove barriers preventing households from recycling. Similarly, Wright, (2011) reported that people who are better informed tend to recycle more.

\section{Conclusions}

The study discovered that, although, a significant number of people in Abuja believe that their waste has value, only a few people actually engage in waste separation and recycling. Some of the reasons for the low level of waste separation and recycling can be attributed to two main reasons; the lack of incentives for residents who engage in recycling activities and the lack of recycling programs and facilities by recycling companies and the government.

Furthermore, the research asserted that a higher public involvement in environmental sanitation and waste management issues such as recycling and waste separation is likely to ensure a clean and healthy environment. Therefore, it is suggested that adequate measures be taken by the environmental protection board to ensure a high level of public participation.

\section{References}

Abba, A. H., Noor, Z. Z., Yusuf, R. O., Din, M. F., \& Hassan, M. A. A. (2013). Assessing environmental impacts of municipal solid waste of Johor by analytical hierarchy process.Resources, Conservation and Recycling, 73, 188-196. http://dx.doi.org/10.1016/j.resconrec.2013.01.003

Al-Jarrah \& Abu-Qdais (2006). Municipal solid waste landfill siting using intelligent system. Waste management, 26(3), 299-306. http://dx.doi.org/10.1016/j.wasman.2005.01.026

Arene, C. J., \& Mbata, G. I. O. (2008).Determinants of profitability and willingness to pay for metropolitan waste-use in urban agriculture of the Federal Capital Territory, Abuja, Nigeria.Agro-Science, 7(1), 41-46. http://dx.doi.org/10.4314/as.v7i1.1582

Babayemi, J. O., \& Dauda, K. T. (2009). Evaluation of solid waste generation, categories and disposal options in developing countries: a case study of Nigeria. Journal of Applied Sciences and Environmental Management, 13(3).

Butu, A. W., \& Mshelia, S. S. (2014). Municipal solid waste disposal and environmental issues in kano metropolis, nigeria. British Journal of Environmental Sciences, 2(1), 1-16. 
Bryman, A., \& Bell, E., (2011). Business Research Methods 3e.Oxford university press.

Bryman, A., (2012). Social research methods.Oxford university press.

Crowther, D. \& Lancaster, G., (2008). Research Methods: A Concise Introduction to Research in Management and Business Consultancy, Butterworth-Heinemann

D'Elia, J. L. I., (2008). Determinants of Household Waste Recycling in Northern Ireland. [WWW Document]. URL http://eservices.afbini.gov.uk/erini/pdf/ERINIMon23.pdf (accessed 4.12.15).

Imam, A., Mohammed, B., Wilson, D. C., \& Cheeseman, C. R. (2008). Solid waste management in Abuja, Nigeria.Waste Management, 28(2), 468-472. http://dx.doi.org/10.1016/j.wasman.2007.01.006

Manhart, A., Osibanjo, O., Aderinto, A., \&Prakash, S. (2011). Informal e-waste management in Lagos, Nigeria-socio-economic impacts and feasibility of inter-national recycling co-operations. Final report of component, 3 .

Nzeadibe, T. C., \& Ajaero, C. K. (2011). Development impact of advocacy initiatives in solid waste management in Nigeria.Environment, development and sustainability, 13(1), 163-177. http://dx.doi.org/10.1007/s10668-010-9254-8

Ogwueleka, T. C. (2009). Municipal solid waste characteristics and management in Nigeria.Iranian Journal of Environmental Health Science \& Engineering, 6(3), 173-180.

Ogunba, O. A. (2004). EIA systems in Nigeria: evolution, current practice and shortcomings. Environmental Impact Assessment Review, 24(6), 643-660. http://dx.doi.org/10.1016/j.eiar.2003.10.019

Omran, A., \& Gavrilescu, M. (2008). Municipal Solid Waste Management in Developing Countries: A Perspective on Vietnam. Environmental Engineering \& Management Journal (EEMJ), 7(4).

Omran, A., Mahmood, A., Abdul Aziz, H., \& Robinson, G. M. (2009). Investigating households attitude toward recycling of solid waste in Malaysia: a case study. International journal of environmental research, 3(2), 275-288.

Onwughara, N. I., Nnorom, I. C., Kanno, O. C., \& Chukwuma, R. C. (2010). Disposal methods and heavy metals released from certain electrical and electronic equipment wastes in Nigeria: adoption of environmental sound recycling system. International Journal of Environmental Science and Development, 1(4), 290-296. http://dx.doi.org/10.7763/IJESD.2010.V1.57

Rahardyan, B., Matsuto, T., Kakuta, Y., \& Tanaka, N. (2004). Resident's concerns and attitudes towards Solid Waste Management facilities. Waste Management, 24(5), 437-451. http://dx.doi.org/10.1016/j.wasman.2003.11.011

Remigios, M. V. (2010). An overview of the management practices at solid waste disposal sites in African cities and towns. Journal of Sustainable Development in Africa, 12(7). 


\section{Macrothink}

Roberts, C. L., Watkin, G. D., Ezeah*, C., Phillips, P. S., \& Odunfa, A. (2010). Seasonal VaritationAnd Municipal Solid Waste Composition-Issues For Development Of New Waste Management Strategies In Abuja, Nigeria. The Journal of Solid Waste Technology and Management, 36(4), 210-219. http://dx.doi.org/10.5276/JSWTM.2010.210

Saeed, M. O., Hassan, M. N., \& Mujeebu, M. A. (2009).Assessment of municipal solid waste generation and recyclable materials potential in Kuala Lumpur, Malaysia.Waste Management, 29(7), 2209-2213. http://dx.doi.org/10.1016/j.wasman.2009.02.017

Solomon, U. U. (2009). The state of solid waste management in Nigeria.Waste Management, 29(10), 2787-2788. http://dx.doi.org/10.1016/j.wasman.2009.06.030

Suberu, M. Y., Mokhtar, A. S., \& Bashir, N. (2012). Renewable power generation opportunity from municipal solid waste: a case study of Lagos Metropolis (Nigeria). Journal of Energy Technologies and Policy, 2(2), 1-14.

Umesi, N. O., \& Onyia, S. (2008). Disposal of e-wastes in Nigeria: an appraisal of regulations and current practices. The International Journal of Sustainable Development \& World Ecology, 15(6), 565-573. http://dx.doi.org/10.1080/13504500809469852

Wright, Y.L., 2011. Relating Recycling: Demographics, Attitudes, Knowledge and Recycling Behavior among UC Berkeley Students [WWW Document]. URL http://nature.berkeley.edu/classes/es196/projects/2011final/WrightY_2011.pdf (accessed 4.13.15).

\section{Copyright Disclaimer}

Copyright for this article is retained by the author(s), with first publication rights granted to the journal.

This is an open-access article distributed under the terms and conditions of the Creative Commons Attribution license (http://creativecommons.org/licenses/by/3.0/). 